\title{
THIN-FILM SILICON PV TECHNOLOGY
}

\begin{abstract}
Miroslav Zeman *
Thin-film silicon solar cell technology is one of the promising photovoltaic technologies for delivering low-cost solar electricity. Today the thin-film silicon PV market ( $402 \mathrm{MW}_{\mathrm{p}}$ produced in 2008) is dominated by amorphous silicon based modules; however it is expected that the tandem amorphous/microcrystalline silicon modules will take over in near future. Solar cell structures based on thin- film silicon for obtaining high efficiency are presented. In order to increase the absorption in thin absorber layers novel approaches for photon management are developed. Module production and application areas are described.

K e y w or d s: amorphous silicon, microcrystalline silicon, solar cells, photon management
\end{abstract}

\section{INTRODUCTION}

In the last eight years (2000-2008) the solar module production has grown on average by more than $40 \%$, which means that the solar module market is one of the fastest growing markets in the world (see Fig. 1). The total production of solar modules reached $7910 \mathrm{MW}_{\mathrm{p}}$ in 2008 and was dominated by crystalline silicon (c-Si) solar cells, which accounted for $87 \%$ of the total production [1]. As the c-Si solar cells, which represent the first generation solar cells for terrestrial applications, have matured, the cost of these solar cells has become dominated by material costs, namely those of the silicon wafer, the glass cover plate, and the encapsulants.

One way to decrease the cost of solar electricity is to reduce the thickness of the semiconductor materials that form a solar cell. In comparison to bulk c-Si solar cells, in which the silicon wafer has a thickness of 200 to 350 micrometers, the total thickness of the semiconductor absorbers in thin-film solar cells is less than a few micrometers. There are several semiconductors that are excellent candidates for thin-film solar cells, such as silicon, copper indium gallium diselenide $\left(\mathrm{CuInGaSe}_{2}=\mathrm{CIGS}\right)$ and cadmium telluride (CdTe). Among thin-film solar cells, a silicon share in the solar module market was in $20085 \%$ (ie $402 \mathrm{MW}_{\mathrm{p}}$ ) of the total production, while the share CdTe solar cells increased to more than $7 \%$ [1].

At present most of the commercial thin-film silicon solar cells are represented by hydrogenated amorphous silicon $(a-\mathrm{Si}: \mathrm{H})$ based solar cells. A distinct feature of these solar cells is that silicon based layers are deposited in a low-temperature regime $\left(T<600{ }^{\circ} \mathrm{C}\right)$ by plasma enhanced chemical vapor deposition techniques. Since in silicon solar cell technology the term "thin-film" usually covers a range of 1 to 100 micrometers thick layers, in this article thin-film silicon solar cells refer to the low temperature silicon based solar cells.

\section{THIN-FILM SILICON SOLAR CELL STRUCTURES}

In 1975 Walter Spear and Peter LeComber reported that amorphous silicon had semiconducting properties by demonstrating that the conductivity could be manipulated by several orders of magnitude by adding some phosphine or diborane gas to the gas mixture [2]. This was a far-reaching discovery since until that time it had been thought that amorphous silicon could not be made $n$-type or $p$-type by substitutional doping. Amorphous silicon suitable for electronic applications, where doping is required, is an alloy of silicon and hydrogen. Therefore, the electronic-grade amorphous silicon is therefore called hydrogenated amorphous silicon.

The successful doping of $a-\mathrm{Si}: \mathrm{H}$ created tremendous interest in this material for two reasons. First, the material had several interesting properties that opened up many opportunities for semiconductor device applications, especially in optoelectronics and photovoltaics $(\mathrm{PV})$. For example, due to the high absorption coefficient of $a-\mathrm{Si}: \mathrm{H}$ in the visible range of the solar spectrum, a $1 \mu \mathrm{m}$ thick $a$-Si:H layer is sufficient to absorb $90 \%$ of the usable solar energy. Second, the glow discharge deposition technique, also referred to as plasma enhanced chemical vapor deposition (PECVD), enabled production of $a$-Si:H films over a large area $\left(>1 \mathrm{~m}^{2}\right)$ and at a low temperature $\left(100{ }^{\circ} \mathrm{C}\right.$ to $\left.400{ }^{\circ} \mathrm{C}\right)$. The low processing temperature allows the use of a wide range of low-cost substrates such as a glass sheet and a metal or polymer foil. The $a$-Si:H can be simply doped and alloyed by adding appropriate gases to a silane source gas. These features made $a$-Si:H a promising candidate for low-cost thin-film solar cells.

Today's thin-film Si solar cells are based on the singlejunction structure. The solar cell structure is such that light enters the intrinsic $a-\mathrm{Si}: \mathrm{H}$ layer that serves as the absorber layer through the $p$-type layer. This is in order to facilitate the collection of holes from the absorber layer, which have a lower mobility than electrons in $a-\mathrm{Si}: \mathrm{H}$. There are two basic configurations of thin-film Si solar

\footnotetext{
* Delft University of Technology, Laboratory of Photovoltaic Materials and Devices, Feldmannweg 17, 2628 CT Delf , Netherlands, m.zeman@tudelft.nl
} 


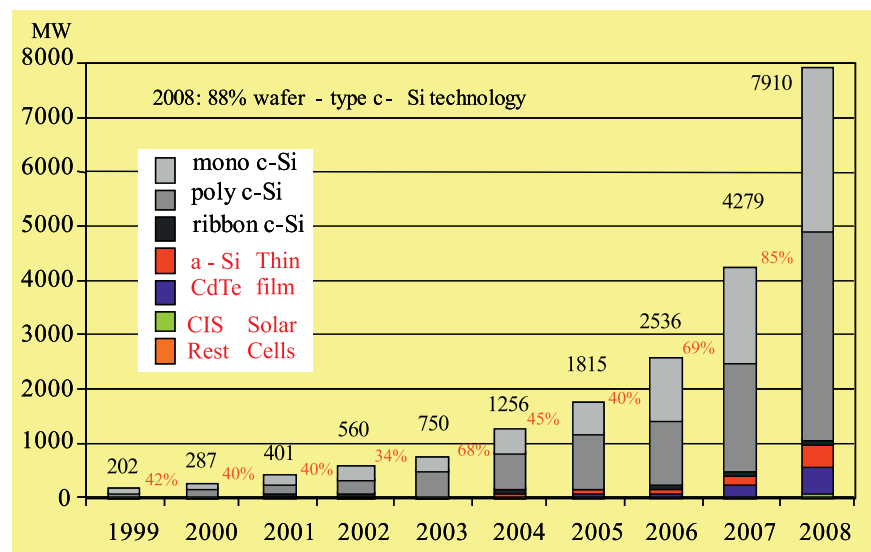

Fig. 1. Global solar cell production between 2000 and 2008 [1]

cells, namely a superstrate and substrate configuration, which depend on the sequence of the silicon layer deposition, $p-i-n$ or $n-i-p$, respectively. In case of the superstrate configuration, the $p-i$ - $n$ deposition sequence requires a transparent substrate carrier. Usually, a glass plate coated with a transparent conductive oxide (TCO) layer with a rough surface is used as the carrier. Figure 2 shows a typical superstrate single-junction $a$-Si:H solar cell. The back contact is a highly reflecting metal layer, usually deposited onto a TCO interlayer, which is used to improve the reflection from the back contact by matching the refractive indices between the n-type silicon and metal. An encapsulant and/or another glass plate usually form the backside of the superstrate cell.

In case of the substrate configuration, the substrate carrier forms the backside of the cell. This allows the use of opaque substrates, such as stainless steel. Also a polymer foil is used as a substrate. Since the polymer need not be transparent a temperature resistant type of polymer can be applied, such as polyimid. The foils can be thin enough to be flexible, which opens up a possibility to employ a roll-to-roll processing. A highly reflecting back contact with textured surface that consists of a metal layer of silver or aluminum and a TCO layer is deposited on the carrier. The surface texture is required in order to scatter the reflected light back to the cell at the angles that are large enough to facilitate total internal reflection. After depositing the sequence of the $n-i-p$ $a-\mathrm{Si}: \mathrm{H}$ based layers a TCO top layer with a metal grid is formed as the top contact. The front side of the substrate cell is finished by a transparent encapsulant layer with an additional glass plate. The use of conductive carriers such as stainless steel complicates the monolithic series interconnection of cells on the substrate.

Some important features of $a$-Si:H solar cells become apparent from Fig. 2. The front contact layer is formed by the TCO. The top TCO film has to fulfill several stringent requirements, such as high optical transmission in the spectrum of interest, low sheet resistance, temperature durability and good chemical stability and adhesion. In the superstrate configuration the surface of the TCO layer has to be textured in order to enhance light

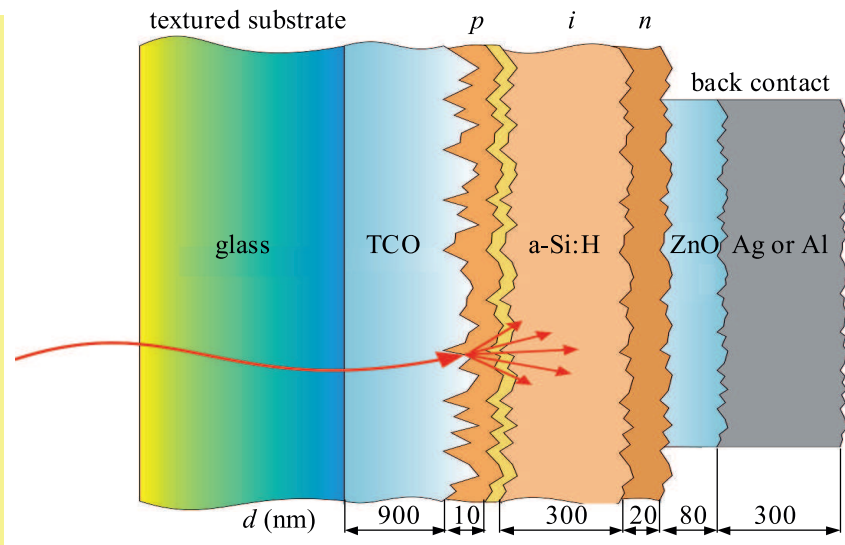

Fig. 2. A schematic structure of a superstrate single junction $a-\mathrm{Si}: \mathrm{H}$ solar cell

absorption inside the solar cell due to the scattering at internal rough interfaces. The carriers generated in the p-type layer do not contribute to the photocurrent and it is thus desirable that the light absorption in this layer is small. A smaller absorption is achieved by alloying the $a$-Si:H with carbon, which increases the optical band gap to about $2 \mathrm{eV}$. A sufficient high electrical conductivity is required for both $p$ - and $n$-type layers in order to form low resistance contacts with the electrodes and a high built-in voltage across the $\mathrm{p}-\mathrm{i}-\mathrm{n}$ junction. The intrinsic layer with an optical band gap of about $1.75 \mathrm{eV}$ serves as an absorber. The thickness of the intrinsic layer can vary between 100 to $300 \mathrm{~nm}$, which depends whether it is incorporated in single or multi-junction cells. Because the intrinsic layer is sandwiched in between the doped layers, an internal electric field is present across the intrinsic layer. The internal electric field facilitates separation of electron-hole pairs that are generated in the intrinsic layer. The electric field strongly depends on the defect distribution inside the intrinsic layer and at the interfaces with the doped layers.

The first $a$-Si:H solar cell was made by Carlson and Wronski in 1976 and exhibited an energy conversion efficiency of $2.4 \%$ [3]. Inherent to $a-\mathrm{Si}: \mathrm{H}$ is the creation of metastable defects when the material is exposed to light. This is a manifestation of what is called a StaeblerWronski effect [4], which is undesirable in solar cells. The extra created defects in the intrinsic layer act as recombination and trap centers for photo-generated charge carriers. As a result of the trapping the space charge distribution in the layer changes and distorts the internal electric field. This leads to a lower drift and thus to a lower collection efficiency. The performance degradation of $a$-Si:H based solar cells due to illumination can be partly avoided by using thinner intrinsic layers in which the internal electric field is higher and therefore less sensitive to any distortion. However, the employment of thinner absorber layers results in a lower absorption. The solution for having cells with better stability is the use of a stacked or multi-junction solar cell structure. The total thickness of the complete cell is the same as for a single junction solar cell, but each component cell is thinner and 

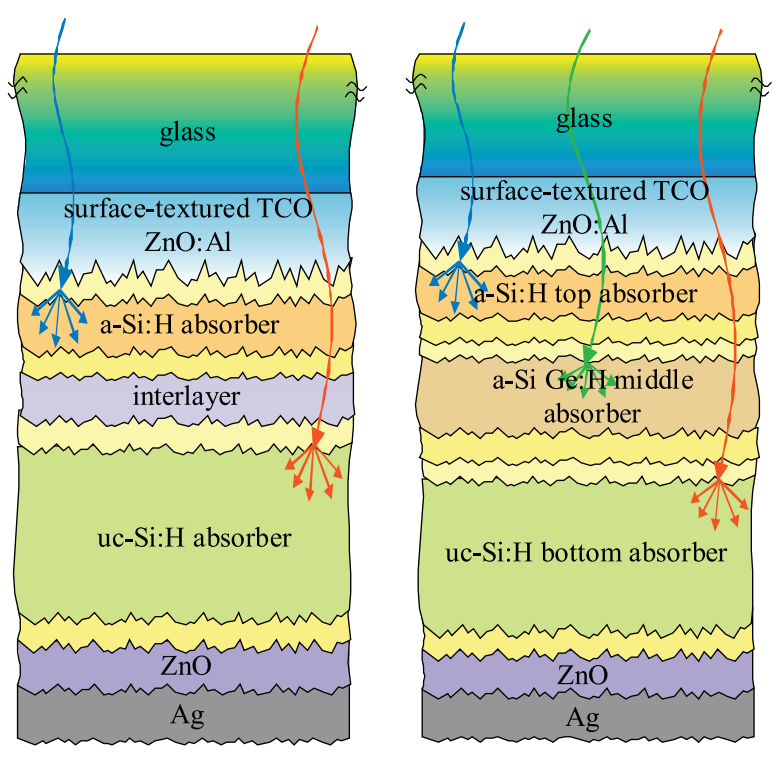

Fig. 3. A schematic structure of a) double-junction and b) triplejunction thin-film Si based solar cell

therefore less sensitive to the light-induced defects. Another way to minimize the Staebler-Wronski effect is to develop an amorphous silicon material that is more stable against light exposure [5].

The concept of a multi-junction solar cell is already widely used in thin-film silicon solar cell technology. In the multi-junction solar cell structure two [6] or more [7] solar cells are stacked on top of each other. Multijunction solar cell approach means that the absorber layer in each component cell can be tailored to a specific part of the solar spectrum. Top cells efficiently absorb short-wavelength part of the spectrum (high energy photons), whereas bottom cells absorb the remaining longwavelength part of the spectrum (low-energy photons). In this way the thermalization losses are minimized, which is reflected in higher open-circuit voltages of the devices. Absorber layers in multi-junction thin-film silicon solar cells are based on $a$-Si:H, alloys of $a$-Si:H such as hydrogenated amorphous silicon germanium ( $a$-SiGe:H) and hydrogenated microcrystalline silicon $(\mu c-\mathrm{Si}: \mathrm{H})$. For a tandem cell, the highest efficiency is predicted for a combination of absorber materials having band gap $1.7 \mathrm{eV}$ and $1.1 \mathrm{eV}$ for the top and bottom cell, respectively. With a band gap of $1.1 \mathrm{eV} \mu c-\mathrm{Si}: \mathrm{H}$ is the ideal material for a tandem cell with $a$-Si:H. The University of Neuchâtel introduced a micromorph tandem solar cell in 1994, which comprised an $a$-Si:H top cell and a $\mu c-\mathrm{Si}: \mathrm{H}$ bottom cell [8]. Additional advantage is the stability of the component $\mu c-\mathrm{Si}: \mathrm{H}$ solar cell against light exposure. The useful thickness of $\mu c-\mathrm{Si}: \mathrm{H}$ absorber is in the range of 1.0 to 3.0 micrometers. In order to obtain current matching a relatively thick (above $300 \mathrm{~nm}$ ) $a$-Si:H layer is required in the top cell, which still suffers from the light induced degradation. It is expected that by implementing improved light trapping techniques, especially for near infrared light, the thickness of both absorber layers can be reduced. The best laboratory stabilized efficiency of a single junction $a-\mathrm{Si}: \mathrm{H}$ cell is $10.02 \%$ [9], of a tandem micromorph $a$-Si:H/c-Si:H cell is $14.1 \%$ (initial) [10] and a triple junction $a-\mathrm{Si}: \mathrm{H} / a-\mathrm{SiGe}: \mathrm{H} / \mu c-\mathrm{Si}: \mathrm{H}$ cell is $11.2 \%$ [11], $a-\mathrm{Si}: \mathrm{H} / a-\mathrm{SiGe}: \mathrm{H} / a-\mathrm{SiGe}: \mathrm{H}$ cell is $10.4 \%$ and $a-\mathrm{Si}: \mathrm{H} / \mu c-\mathrm{Si}: \mathrm{H} / \mu c-\mathrm{Si}: \mathrm{H}$ cell is $12.2 \%$ [12]. In Fig. 3a and Fig. 3b a typical double-junction silicon solar cell structure and a triple-junction solar cell structure are presented, respectively.

Light trapping techniques help to capture light in the desired parts of a solar cell, which are the absorber layers, and prevent it from escaping. The most important role of light trapping is to keep the physical thickness of the absorber layer as thin as possible and to maximize its effective optical thickness. The following techniques are used to trap photons inside the absorber layer [13]

- in-coupling of incident photons at the front side,

- reflection at the back side,

- intermediate reflectors in tandem solar cells,

- scattering at rough interfaces,

- scattering at metal nano-particles (plasmonic effects).

Two research areas can be distinguished regarding the development of light trapping techniques. The first area deals with the manipulation of photon propagation throughout a solar cell. The techniques are related to the development and implementation of optically-active layers such as anti-reflection coatings, single or stack of layers for index matching, intermediate and back reflectors [14]. These layers take care that photons reach the absorber layer and inside the absorber undergo multiple passes. The second area deals with the enhancement of an average photon path length inside the absorber layer. This is achieved by scattering of light at rough interfaces and/or metal nano-particles. These techniques are related to the design and fabrication of a surface texture on substrate carriers. The surface texture of a substrate introduces rough interfaces into the solar cell structure. Scattering at rough interfaces prolongs the effective path length of photons and partially leads to the total internal reflection between the back and front contacts confining the light inside the absorber. Recently, layers of metal nano-particles and composite materials with embedded metal nano-particles for efficient incoupling and scattering of light into the absorber layer have attracted a lot of attention.

In today's thin-film silicon solar cells the standard trapping techniques are based on scattering of light at rough interfaces, the employment of high-reflective layers at the back contacts and refractive-index matching layers. The rough interfaces are introduced into the solar cell by using substrate carriers that are coated with a randomly surface-textured transparent conductive oxide (TCO) layer, such as fluorine-doped tin oxide (FTO) of Asahi U-type substrate with a pyramidal-like surface structure (see Fig. 4a) and sputtered aluminum-doped zinc oxide (AZO) that after etching in an $\mathrm{HCl}$ solution shows a crater-like surface texture (see Fig. 4b). 



Fig. 4. a) Pyramidal-like and b) crater-like surface morphology of TCO layers
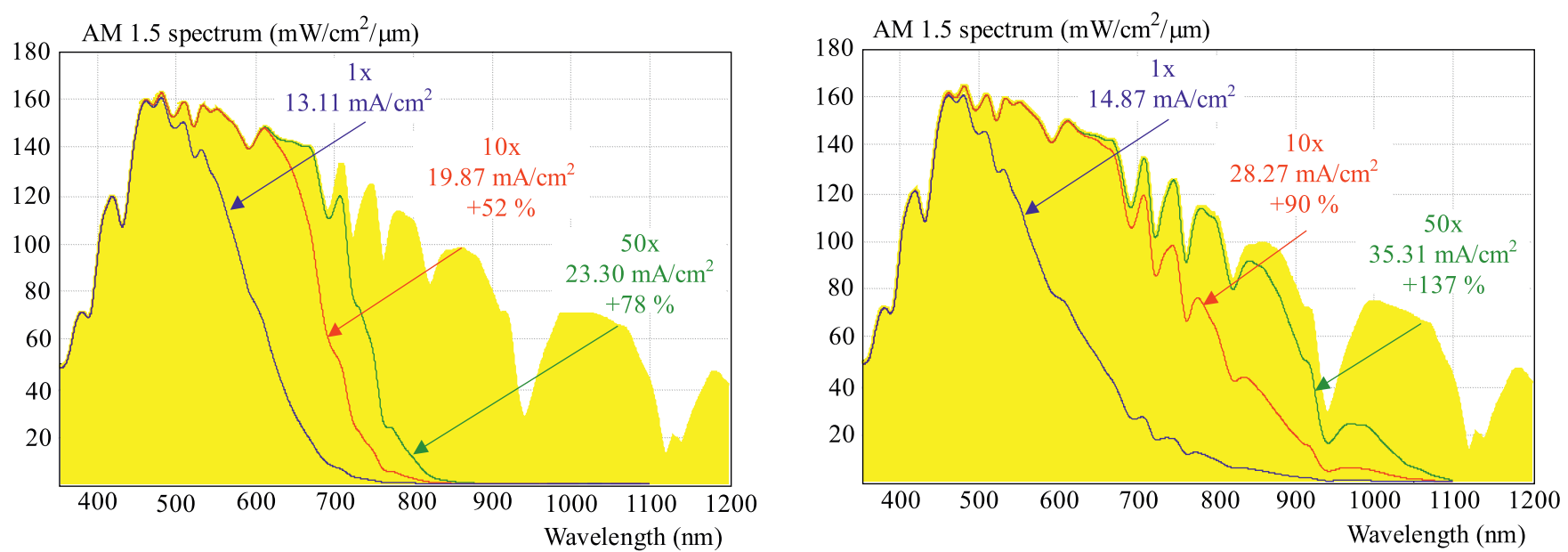

Fig. 5. Spectral absorption in a) $300 \mathrm{~nm}$ thick $a$-Si:H layer and b) $1 \mu \mathrm{m}$ thick $\mu c-\mathrm{Si}: \mathrm{H}$ layer matched to the AM1.5 spectrum, when the effective optical thickness of the layers is increased 10 and 50 times [13]

\section{CHALLENGES OF THIN-FILM SI PV TECHNOLOGY}

The challenge in TF Si solar cell technology today is to increase the stabilized conversion efficiency. Future research involves the following areas:

- improvement of the opto-electronic quality of $a$-Si:H, $a$-SiGe:H and $\mu c-\mathrm{Si}: \mathrm{H}$ absorbers,

- full understanding of metastable changes in the properties of $a$-Si:H based materials under light exposure,

- optimization of the doped $p$ - and $n$-type layers and the interfaces between the doped layers and intrinsic absorbers, the role of buffer and profiled layers,

- development of the TCO front material and optimization of the TCO $/ p$-type layer interface,

- photon management for effective use of the energy of the solar radiation and the maximization of absorption in desired parts of a solar cell that are called absorbers,

- increasing the deposition rate of absorber materials while maintaining their quality.

Photon management is one of the key issues for improving the performance of thin-film silicon solar cells and decreasing the production costs by shortening deposition times and using less material. The aim of the photon management is the effective use of the energy of the solar radiation and the maximization of absorption in desired parts of a solar cell that are called absorbers. Photon management in thin-film solar cells is accomplished by a number of techniques that are related to the following areas:

1. effective use of the solar spectrum,

2. minimization of absorption outside the absorber layers,

3. trapping of photons inside the absorber layers (light trapping techniques).

Computer simulations using advanced programs such as the ASA program from Delft University of Technology [15] and the Sunshine program from Ljubljana University [16] are a valuable tool to investigate the potential of photon management in thin-film silicon solar cells. Fig. 5a and $5 \mathrm{~b}$ shows calculated spectral absorption in a $300 \mathrm{~nm}$ thick $a$-Si:H layer and $1 \mu \mathrm{m}$ thick $\mu c$-Si:H layer, respectively, when the effective optical thickness of the layers is increased 10 and 50 times. When matching the absorption in the layers to the AM1.5 spectrum one can calculate a potential photocurrent generated in the layers when used as absorbers in thin-film silicon solar cells. Increasing the optical thickness of the $a$-Si:H layer 10 and 50 times 


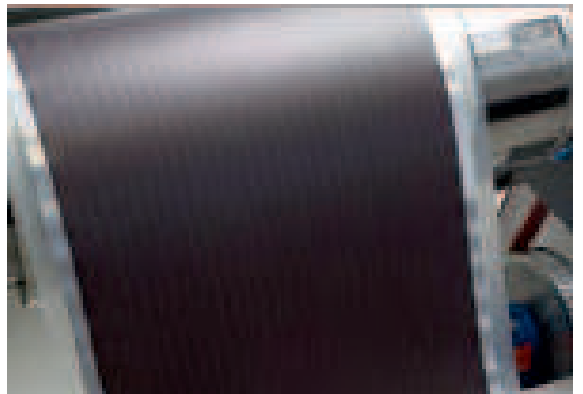

Fig. 6. A flexible module from the Nuon Helianthos company [22]

results in $52 \%$ and $78 \%$ potential enhancement of the photocurrent, respectively. The simulations demonstrate that in case of $\mu c-\mathrm{Si}: \mathrm{H}$ absorber the light trapping plays even more important role. Increasing the optical thickness of $1 \mu \mathrm{m}$ thick $\mu c$-Si:H layer 10 and 50 times results in $90 \%$ and $138 \%$ enhancement of the photocurrent, delivering potential photocurrent of 28 and $35 \mathrm{~mA} / \mathrm{cm}^{2}$, respectively.

\section{FABRICATION OF THIN-FILM SI MODULES}

Thin-film silicon solar cells have improved considerably, capable of achieving initial efficiencies exceeding $15 \%$ (tandem micromorph) $[17,18]$. Based on the companies' announcements the production capacity of thin-film silicon photovoltaic modules is expected to grow to almost $8 \mathrm{GW}$ in the year 2010. The thin-film silicon PV market is dominated by amorphous silicon based modules; however it is expected that the micromorph tandem modules will take over in near future.

The electrical power delivered from a small area solar cell is not enough for practical applications. Therefore, solar cells are connected in series and/or parallel to form a module that delivers a required power and voltage. A key step to practical industrial production of $a$-Si:H solar cells was the development of the monolithically integrated type of $a-\mathrm{Si}: \mathrm{H}$ solar cell [19]. Monolithic series connection of cells to modules that can be easily implemented in the fabrication process is an attractive feature of thin-film $\mathrm{Si}$ solar cell technology.

The manufacturing for amorphous silicon solar cells is divided into two routes, processing on glass plates and processing on flexible substrates. Both manufacturing approaches include the following main steps:

- substrate conditioning,

- large-area deposition of the contact layers, ie the TCO as front electrode and the back reflector that is usually a double layer of metal and TCO,

- large-area deposition of thin Si:H based layers,

- monolithic series connection of cells (at present applied only for manufacturing on glass) using laser scribing of contact and silicon layers,
- final module assembly including encapsulation, applying electrical connections, and framing.

A novel approach to fabricate $a-\mathrm{Si}: \mathrm{H}$ modules has been developed in the Netherlands in the Helianthos project coordinated by the multinational corporation Akzo Nobel [20] and since 2006 by Nuon Helianthos company. The aim is to demonstrate that flexible thin film silicon PV modules manufactured by means of automated roll-to-roll processes offer a versatile light weight thin film silicon PV product that will offer competitive $\mathrm{kWh}$ costs in a wide range of applications [21]. The production technology is based on a temporary superstrate concept, which combines the advantages of both superstrate- and substratetype $a$-Si:H solar cell technologies. The deposition of a high quality top TCO layer using the atmospheric pressure CVD and monolithic series integration that offers the superstrate technology is combined with the roll-to-roll processing that is used in the substrate technology. An example of a flexible module from the Nuon Helianthos company is in Fig. 6.

\section{APPLICATIONS}

Due to the versatility of thin-film Si technology to produce rigid as well as flexible modules and the high energy yield, the application possibilities for thin-film Si based modules are very broad. $a$-Si:H modules have a substantially lower conversion efficiency temperature coefficient than crystalline silicon modules [23], which results in superior performance at higher operational temperatures. This feature favours the implementation of $a-\mathrm{Si}: \mathrm{H}$ modules in high-temperature conditions.

The applications cover the following market areas:

- Consumer products where small solar cells provide electricity for calculators, watches. Small modules with power ranging from 3 to $50 \mathrm{Wp}$ are used as (portable) battery chargers, in car roofs and a variety of other leisure products.

- Residential and commercial grid-connected systems that are mainly designed for Building-Integrated Photovoltaics (BIPV). The modules usually have a 20year power-output warranty and can be structurally and aesthetically integrated as roofing or faade elements. Taking advantage of the laser techniques that are applied during manufacturing of $a-\mathrm{Si}: \mathrm{H}$ modules, partly transparent modules can be fabricated. Offering both environmentally friendly performance and a compelling design, these type of products open new possibilities in BIPV applications.

- Several large grid-connected systems have been realized with thin-film Si based modules. An example is the amorphous silicon solar power plant (installed power of $1 \mathrm{MW}_{\mathrm{p}}$ ) that was completed in the beginning of 2005 in the German city of Buttenwiesen in the suburbs of Munich. The power plant comprises approximately 10000 amorphous silicon single-junction superstrate-type modules. The plant is annually expected to deliver 1 million $\mathrm{kWh}$. 
- Off-grid and remote-area applications include solar systems with a rated power of 30 to $50 \mathrm{~W}_{\mathrm{p}}$ that are mainly designed for lighting in remote homes and construction sites without access to the power grid. Larger systems are designed to generate power for villages, remote homes, water pumping, telecommunications, traffic control signals, etc.

- Special applications. The lightweight, flexible features of thin-film silicon modules in connection with the inherent radiation hardness and superior hightemperature performance make the technology a candidate for space PV application.

\section{CONCLUSIONS}

The flexibility of thin-film silicon solar cell technology to deliver modules for a large variety of applications is its most important asset. The technology has a strong potential to produce modules with an attractive costto-performance ratio generating electricity with a price competitive to that of conventional electricity. The cost reduction of thin-film silicon modules will be determined by the scaling rate of the production capacity. At present, thin-film silicon solar cell technology has to concentrate on solving several issues which are discussed in the section on challenges in order to become a fully mature technology.

Further development of thin-film silicon solar cell technology in general requires an increase in the performance of solar cells. One has to realize that two thirds of the power generated by a promising micromorph tandem ( $a$-Si:H / c-Si:H) solar cell comes from the $a$-Si:H top cell. In the near future, attention will be paid to enhancing light trapping inside the cells, ie improving the TCO material quality and optimising the surface texture. At the same time, research will continue on $a$-Si:H based materials, which has recently resulted in a completely new class of nano-structured silicon films.

\section{Acknowledgements}

The author thanks Janez Krč from Ljubljana University for contributing to this article.

\section{REFERENCES}

[1] Photon International, March 2009.

[2] SPEAR, W.-LeCOMBER, P.: Solid State Comm. 17 (9) (1975), 1193.

[3] CARlson, D. E.-WROnski, C. R.: Appl. Phys. Lett. 28 (11) (1976), 671.

[4] StAeBleR, D. L.-WRONSKI, C. R.: Appl. Phys. Lett. 31 (1977), 292.

[5] ZEMAN, M.-'van ELZAKKER, G.-TICHELAAR, F. D.SUTTA, P.: Philosophical Magazine 89:28 (2009), 2435-2448.

[6] FISCHER, D. et al : Proc. $25^{\text {th }}$ IEEE PVSC, Washington, DC, 1996, p. 1053.

[7] GUHA, S. et al: Proc. PVSEC-15, 2005, Shanghai, China,, p. 35 .
[8] MEIER, J. et al: in Proc. of the $1^{\text {st }}$ WPSEC, Hawai, USA, 1994, p. 409.

[9] BENAGLI, S.-BORRELLO, D. et al : Proc. 24 ${ }^{\text {th }}$ EUPVSEC, Hamburg, Germany, 2009.

10] YAMAmOtO, K.-YOShimi, M. et al : Sol. En. Mat. and Solar Cells 74 (1-4) (2002), 449-455.

11] YUE, G.-YAN, B.-OWENS, J. M.-YANG, J.-GUHA, S. : Mater. Res. Soc. Symp. Proc. 808 (2004), 808-A09-43.

[12] GREEN, M. A.-EMERY, K.-HISHIKAWA, Y.-WARTA, W.: Prog. Photovolt. Res. Appl. 17 (2009), 320.

13] ZEMAN, M.-ISABELlA, O.et al: Mater. Res. Soc. Symp. Proc. 1245 (2010), 1245-A03-03.

[14] DAGAMSEH, A. M. K.-VET, B. et al : Thin Solid Films, 516 (21) (2008), 7844-7850.

[15] ZEMAn, M.-WILlEMEn, J. A.et al : Sol. Energ. Mat. Sol. C. 46 (1997), 81.

[16] KRČ, J.-SMOLE, F.-TOPIC, M.: Prog. Photovolt. Res. Appl. 11 (2003), 15.

17] YANG, J.-BANERJEE, A.-LORD, K.-GUHA, S. : in Proc. of the $2^{\text {nd }}$ WPSEC, Vienna, Austria, 1998, p. 387.

18] ZEMAN, M.-KRČ, J.: Journal of Materials Research 23 (4) (2008), 889.

19] KUWANO, Y.-IMAI, T.-OHNISHI, M.-NAKANO, S. : A Horizontal Cascade Type Amorphous Si Photovoltaic Cell Module, in Proceedings of the $14^{\text {th }}$ IEEE Photovoltaic Specialist Conference, 1980, p. 1408.

20] MIDDELMAN, E. van ANDEL, E. et al: Proceedings of the $2^{\text {nd }}$ World Conference and Exhibition on Photovoltaic Solar Energy Conversion, vol. I., 1998, pp. 816-819.

[21] JONGERDEN, G. J.: Monolithically Series Integrated Flexible PV Modules Manufactured on Comodity Polymer Substrates, in Proceedings of the $3^{\text {rd }}$ World Conference and Exhibition on Photovoltaic Solar Energy Conversion, Osaka, 2003, p. $6 \mathrm{LN}-\mathrm{C}-05$.

22] http://www.nuon.com/nl/het-bedrijf/innovatieve-projecten/ helianthos/index.jsp.

[23] LECHneR, P.-SCHADE, H. : Progress in Photovoltaics: Research and Applications 10 (2002), 85-97.

Received 30 June 2010

Miroslav Zeman was born in Žilina, Slovakia, on June 21, 1957. He received the PhD degree in 1989 from the University of Technology, Bratislava, Slovakia for his work on the fabrication of devices for electronics based on amorphous silicon. Since 1989 he has been at Delft University of Technology in the Netherlands where he has been in charge of more than 30 projects related to thin-film silicon solar cells. In 2009 he was appointed a full professor at Delft University of Technology for the chair of Photovoltaic Materials and Devices in the department of Electrical Sustainable Energy. His research interests are the development of novel concepts for the improvement of thin-film silicon solar cell performance, modeling of devices based on amorphous and crystalline semiconductors and practical implementation of photovoltaics. He is an author and co-author of more than 200 scientific publications; contributed to three scientific books, and together with Prof. R.E.I. Schropp he wrote a book on thin-film silicon solar cells that was published in USA by Kluwer Academic Publishers.

This work was presented at International Conference Energetika 2010, May 18-20, 2010, Vysoké Tatry - Tatranské Matliare, Slovakia. 